\title{
Additional Treatment of Vitamin D for Improvement of Insulin Resistance in Non-Alcoholic Fatty Liver Disease Patients: A Systematic Review and Meta-Analysis
}

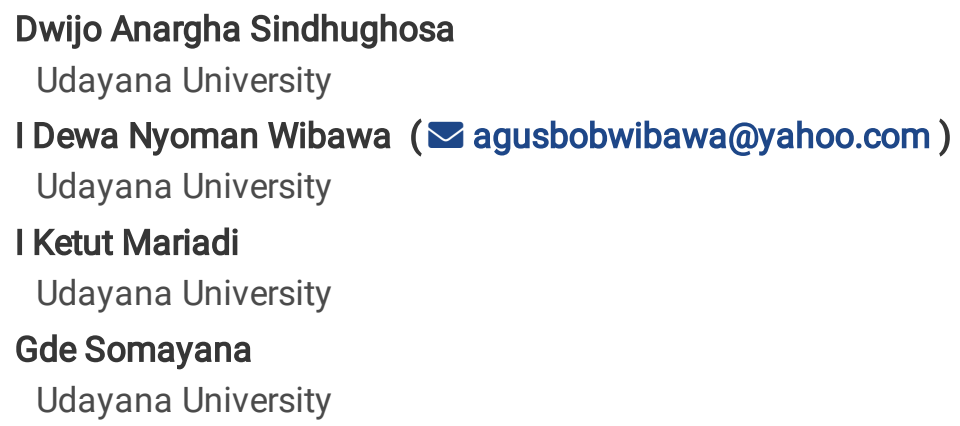

Research Article

Keywords: Vitamin D supplementation, insulin resistance, HOMA-IR, NAFLD

Posted Date: July 20th, 2021

DOI: https://doi.org/10.21203/rs.3.rs-713287/v1

License: (c) (i) This work is licensed under a Creative Commons Attribution 4.0 International License. Read Full License 


\section{Abstract}

Insulin resistance provide important role in pathogenesis of non-alcoholic fatty liver disease (NAFLD). Several studies already evaluate vitamin D supplementation for NAFLD patients, in relation to insulin resistance. The results obtained still carry conflicting results. This study aimed to evaluate the effect of additional treatment of vitamin $D$ for improvement of insulin resistance in NAFLD patients. Relevant literatures were obtained from PubMed, Google Scholar, COCHRANE, and Science Direct database. The obtained studies were analyzed using fixed effect model or random effect model. Seven eligible studies with a total of 735 participants were included. Vitamin D supplementation improve insulin resistance in NAFLD patients, marked by reduce of Homeostatic Model Assessment for Insulin Resistance (HOMA-IR), with pooled mean difference - 1.06 ( $p$ $=0.0006 ; 95 \% \mathrm{Cl}:-1.66$ to -0.45$)$. Vitamin D supplementation increase the level of vitamin D serum with pooled mean difference of 17.45 ( $p=0.0002 ; 95 \% \mathrm{Cl}: 8.33$ to 26.56 ). Vitamin D supplementation decrease ALT levels, with pooled mean difference of -4.44 ( $p=0.02 ; 95 \% \mathrm{Cl}$ : -8.24 to -0.65$)$. No effect observed for AST levels. Vitamin D supplementation provide beneficial effects on improvement of insulin resistance in NAFLD patients. This supplementation may reduce HOMA-IR in such patients. It may serve as potential adjunctive treatment for NAFLD patients.

\section{Introduction}

Non-alcoholic fatty liver disease (NAFLD) is a spectrum of fat-associated liver condition. ${ }^{1}$ It is characterized with high accumulation of triglycerides in hepatocytes, often accompanied with necro-inflammatory activity and fibrosis (steatohepatitis). ${ }^{2}$ It may develop to non-alcoholic steatohepatitis (NASH), fibrosis and cirrhosis. NAFLD has been known as major cause of chronic liver disease, with increasing in prevalence, estimated as $25-30 \%$ among adults in developed countries. ${ }^{3,4}$ Insulin resistance, inflammation and oxidative stress considered as main factor in the development of NAFLD. ${ }^{1}$

The pathogenesis mechanism of NAFLD closely related to insulin resistance. Based on the most widespread model of "two-hit hypothesis", insulin resistance involved for the process of the "first hit". In this initial mechanism, it involves accumulation of lipids located at the hepatocytes, in which insulin resistance presumed as main pathogenic factor for development of hepatic steatosis. The "first hit" increase the vulnerability of liver to factors that constitute the "second hit". It may leads to hepatic injury, inflammation and fibrosis. The generation of proinflammatory cytokines, mitochondrial dysfunction, oxidative stress and lipid peroxidation also adipokines constituted as factors which may promote the development of hepatic injury. ${ }^{5}$

Vitamin D is a fat-soluble vitamin that regulates bone homeostasis. Its role has been widely explored, ranging to non-skeletal health diseases, e.g. metabolic syndrome, insulin resistance, obesity, type 2 diabetes, and cardiovascular-related disease. Recently, a considerable scientific evidence explored the association of vitamin D and NAFLD. Vitamin D has been known to regulate insulin resistance, chronic inflammation, and fibrogenesis, hence vitamin $\mathrm{D}$ may benefit for preventing the progression of NAFLD. ${ }^{6}$

Several randomized controlled trials (RCTs) has evaluate the effect of vitamin D supplementation for insulin resistance. However, the results obtained still vary, either showed beneficial effect toward insulin resistance or showed no benefit. 7,8,9,10,11,12,13 In spite of all conflicting results, meta-analysis to evaluate the overall effect of vitamin D supplementation still required. The current study aimed to evaluate the effect of vitamin D supplementation toward insulin resistance.

\section{Results}

\section{Study Selection}

By utilizing the foremost search strategy, we found a total of 207 studies and after the duplicates removed, we obtained 199 articles. We excluded 182 articles by screening the titles and abstracts, left us a total of 17 relevant studies. Studies which not provided all the information needed for this meta-analysis or full-text not available were excluded. Screening and qualitative 
evaluation were performed, then we obtained 7 articles which used for the current systematic review and meta-analysis. PRISMA study flow diagram depicted in Fig. 1.

\section{Study Characteristics}

We included seven full-text articles of Randomized Control Trial (RCT). The publication year of these articles varied between

2012 to 2020 with a total of 423 samples for intervention group and 312 samples for placebo group. The experiment group receive vitamin $\mathrm{D}$ supplementation in varying doses and duration, while the control group receive placebo. The summary of finding and studies characteristics can be seen in Table 1. 
Table 1

Summary of findings and Studies Characteristics

\begin{tabular}{|c|c|c|c|c|c|c|c|}
\hline Author & $\begin{array}{l}\text { Type of } \\
\text { Study }\end{array}$ & population & $\begin{array}{l}\text { Doses of } \\
\text { Vitamin D and } \\
\text { comparator }\end{array}$ & Duration & $\begin{array}{l}\text { Sample } \\
\text { Size, } \\
\text { experiment } \\
\text { vs control }\end{array}$ & $\begin{array}{l}\text { Age, } \\
\text { experiment } \\
\text { vs control }\end{array}$ & $\begin{array}{l}\text { Baseline } \\
\text { HOMA-IR, } \\
\text { experiment } \\
\text { vs control }\end{array}$ \\
\hline $\begin{array}{l}\text { Amiri et } \\
\text { al. } \\
(2016)^{7}\end{array}$ & $\begin{array}{l}\text { Randomized } \\
\text { double blind } \\
\text { placebo- } \\
\text { controlled } \\
\text { trial }\end{array}$ & $\begin{array}{l}\text { NAFLD according } \\
\text { to ultra- } \\
\text { sonography }\end{array}$ & $\begin{array}{l}1000 \mathrm{IU} \\
\text { supplement of } \\
\text { vitamin D } \\
(25 \mu \mathrm{g} / \mathrm{d} \text { as } \\
\text { calcitriol; } \\
\text { Jalinus Arya } \\
\text { Co. Iran). } \\
\text { Comparator: } \\
\text { Placebo ( } 25 \\
\mu \mathrm{g} / \mathrm{d} \text { as lactose; } \\
\text { Jalinus Arya } \\
\text { Co. Iran) }\end{array}$ & $\begin{array}{l}12 \\
\text { weeks }\end{array}$ & $\begin{array}{l}37 \\
\text { subjects } \\
\text { vs } 36 \\
\text { subjects }\end{array}$ & $\begin{array}{l}39.8 \pm 11 \\
\text { vs } 44 \pm \\
10.8\end{array}$ & $\begin{array}{l}4.3 \pm 1.5 \\
\text { vs } 3.55 \pm \\
1.3\end{array}$ \\
\hline $\begin{array}{l}\text { Barchetta } \\
\text { et al. } \\
(2016)^{8}\end{array}$ & $\begin{array}{l}\text { Monocentric, } \\
\text { randomized, } \\
\text { double-blind, } \\
\text { placebo } \\
\text { controlled } \\
\text { trial }\end{array}$ & $\begin{array}{l}\text { T2D patients } \\
\text { affected } \\
\text { by NAFLD }\end{array}$ & $\begin{array}{l}\text { Cholecalciferol } \\
25.000 \mathrm{IU} / 2.5 \\
\mathrm{~mL}) . \\
\text { Comparator: } \\
\text { Placebo }\end{array}$ & $\begin{array}{l}24 \\
\text { weeks }\end{array}$ & $\begin{array}{l}26 \\
\text { subjects } \\
\text { vs } 29 \\
\text { subjects }\end{array}$ & $\begin{array}{l}57.4 \pm 10.7 \\
\text { vs } 59.8 \pm \\
9.1\end{array}$ & $\begin{array}{l}3.57 \pm 1.9 \\
\text { vs } 3.87 \pm \\
1.6\end{array}$ \\
\hline $\begin{array}{l}\text { Foroughi } \\
\text { et al. } \\
(2016)^{9}\end{array}$ & $\begin{array}{l}\text { Randomized } \\
\text { controlled } \\
\text { trial }\end{array}$ & $\begin{array}{l}\text { NAFDL confirmed } \\
\text { by ultrasound }\end{array}$ & $\begin{array}{l}\text { Vitamin D3 } \\
50,000 \text { IU every } \\
\text { week. } \\
\text { Comparator: } \\
\text { Placebo }\end{array}$ & $\begin{array}{l}10 \\
\text { weeks }\end{array}$ & $\begin{array}{l}30 \\
\text { subjects } \\
\text { vs } 30 \\
\text { subjects }\end{array}$ & $\begin{array}{l}\text { Mean age } \\
\text { of all } \\
\text { participant } \\
\text { was } 48.5 \\
\text { years. No } \\
\text { data o } \\
\text { between } \\
\text { group }\end{array}$ & $\begin{array}{l}3.1 \pm 0.33 \\
\text { vs } 3.12 \pm \\
0.13\end{array}$ \\
\hline $\begin{array}{l}\text { Hussain } \\
\text { et al. } \\
(2019)^{10}\end{array}$ & $\begin{array}{l}\text { Double blind } \\
\text { randomized } \\
\text { placebo } \\
\text { controlled } \\
\text { trial }\end{array}$ & $\begin{array}{l}\text { NAFLD patients } \\
\text { by sonographic } \\
\text { findings }\end{array}$ & $\begin{array}{l}\text { Vitamin D3 } \\
50,000 \text { IU orally } \\
\text { weekly. } \\
\text { Comparator: } \\
\text { Placebo }\end{array}$ & $\begin{array}{l}12 \\
\text { weeks }\end{array}$ & $\begin{array}{l}51 \\
\text { subjects } \\
\text { vs } 51 \\
\text { subjects }\end{array}$ & $\begin{array}{l}27 \pm 1.7 \text { vs } \\
29 \pm 19\end{array}$ & $\begin{array}{l}4.56 \pm 1.6 \\
\text { vs } 4.32 \pm \\
2.25\end{array}$ \\
\hline $\begin{array}{l}\text { Sakpal et } \\
\text { al. } \\
(2017)^{11}\end{array}$ & $\begin{array}{l}\text { Randomized } \\
\text { controlled } \\
\text { trial }\end{array}$ & $\begin{array}{l}\text { NAFLD with } \\
\text { normal or } \\
\text { raised serum } \\
\text { alanine } \\
\text { aminotransferase } \\
\text { (ALT) }\end{array}$ & $\begin{array}{l}\text { Single } \\
\text { injection of } \\
\text { vitamin D } \\
(600,000 \mathrm{U}) \\
\text { given } \\
\text { intramuscularly. } \\
\text { Comparator: } \\
\text { Lifestyle } \\
\text { modifications. } \\
\text { *Note: all } \\
\text { groups received } \\
\text { standard } \\
\text { medical } \\
\text { treatment }\end{array}$ & $\begin{array}{l}6 \\
\text { months }\end{array}$ & $\begin{array}{l}51 \\
\text { subjects } \\
\text { vs } 30 \\
\text { subjects }\end{array}$ & $\begin{array}{l}37 \pm 10 \text { vs } \\
40 \pm 10\end{array}$ & $\begin{array}{l}2.7 \pm 2.1 \\
\text { vs } 1.8 \pm \\
1.6\end{array}$ \\
\hline
\end{tabular}




\begin{tabular}{|c|c|c|c|c|c|c|c|}
\hline Author & $\begin{array}{l}\text { Type of } \\
\text { Study }\end{array}$ & population & $\begin{array}{l}\text { Doses of } \\
\text { Vitamin D and } \\
\text { comparator }\end{array}$ & Duration & $\begin{array}{l}\text { Sample } \\
\text { Size, } \\
\text { experiment } \\
\text { vs control }\end{array}$ & $\begin{array}{l}\text { Age, } \\
\text { experiment } \\
\text { vs control }\end{array}$ & $\begin{array}{l}\text { Baseline } \\
\text { HOMA-IR, } \\
\text { experiment } \\
\text { vs control }\end{array}$ \\
\hline $\begin{array}{l}\text { Sharifi et } \\
\text { al } \\
(2014)^{12}\end{array}$ & $\begin{array}{l}\text { Randomized, } \\
\text { double-blind, } \\
\text { placebo- } \\
\text { controlled } \\
\text { trial with } \\
\text { parallel } \\
\text { design }\end{array}$ & $\begin{array}{l}\text { NAFLD by } \\
\text { ultrasonography } \\
\text { scan and } \\
\text { increased } \\
\text { levels of alanine } \\
\text { transaminase } \\
\text { (ALT) }\end{array}$ & $\begin{array}{l}\text { 50,000 IU } \\
\text { vitamin D3 (D- } \\
\text { Vitin 50,000; } \\
\text { Zahravi Pharm } \\
\text { Co, Tabriz, Iran) } \\
\text { every } 14 \text { days. } \\
\text { Comparator: } \\
\text { placebo }\end{array}$ & $\begin{array}{l}4 \\
\text { months }\end{array}$ & $\begin{array}{l}27 \\
\text { subjects } \\
\text { vs } 26 \\
\text { subjects }\end{array}$ & $\begin{array}{l}40.33 \pm \\
8.65 \text { vs } \\
43.92 \pm \\
9.51\end{array}$ & $\begin{array}{l}3.51 \text { (2.61, } \\
4.98) \text { vs } \\
2.52(1.97, \\
3.32)^{a}\end{array}$ \\
\hline $\begin{array}{l}\text { Vesna et } \\
\text { al } \\
(2020)^{13}\end{array}$ & $\begin{array}{l}\text { Randomized, } \\
\text { double-blind } \\
\text { placebo- } \\
\text { controlled }\end{array}$ & $\begin{array}{l}\text { Adult patients } \\
\text { with NAFLD } \\
\text { confirmed by } \\
\text { ultrasound and } \\
\text { transient } \\
\text { elastography } \\
\text { (TE) }\end{array}$ & $\begin{array}{l}\text { Vitamin D3 } \\
\text { oral solution } \\
\text { (1000 IU/day; } \\
\text { delivered as } 5 \\
\text { drops, } 200 \text { IU } \\
\text { each). } \\
\text { Comparator: } \\
\text { Placebo }\end{array}$ & $\begin{array}{l}12 \\
\text { months }\end{array}$ & $\begin{array}{l}201 \\
\text { subjects } \\
\text { vs } 110 \\
\text { subjects }\end{array}$ & $\begin{array}{l}64(20- \\
85) \text { vs } 66 \\
(23-83)^{b}\end{array}$ & $\begin{array}{l}4.5(0.45- \\
146) \text { vs } \\
4.6(0.68- \\
121)^{b}\end{array}$ \\
\hline $\begin{array}{l}\text { HOMA-IR: } \\
\text { All data pr } \\
{ }^{a} \text { Data pres } \\
{ }^{b} \text { Data pres }\end{array}$ & $\begin{array}{l}\text { omeostatic Mo } \\
\text { sented as mean } \\
\text { nted as median } \\
\text { nted as median }\end{array}$ & $\begin{array}{l}\text { el Assessment for } \\
\text { SD, unless indicat } \\
\text { Q1, Q3) } \\
\text { (range) }\end{array}$ & $\begin{array}{l}\text { otherwise } \\
\text { othestance }\end{array}$ & & & & \\
\hline
\end{tabular}

\section{Risk of Bias Within Studies}

The risk of bias was analyzed using Cochrane Collaboration's risk-of-bias method. All 7 articles which included in the current study passed the evaluation of quality. The complete result of risk of bias for all included articles described in Fig. 2.

\section{Effect of Vitamin D Supplementation on Insulin Resistance of NAFLD Patients}

Vitamin D supplementation improve insulin resistance in NAFLD patients, marked by decrease of HOMA-IR. Based in random effect model $\left(I^{2}=67 \% ; \chi 2=18.46 ; p=0.005\right)$, pooled mean difference between vitamin $D$ supplementation and without vitamin D supplementation was $-1.06(p=0.0006 ; 95 \% \mathrm{Cl}:-1.66$ to -0.45$)$ (Fig. 3$)$.

\section{Effect of Vitamin D Supplementation on Serum Vitamin D and Liver Enzymes of NAFLD Patients}

Pooled mean difference of vitamin D serum after vitamin D supplementation was 17.45 ( $p=0.0002 ; 95 \%$ Cl: 8.33 to 26.56 ), based on random effect model (Fig. 4). Accordance to the analysis, vitamin D supplementation increase the level of vitamin $D$ serum by $17.5 \mathrm{ng} / \mathrm{mL}$. Meanwhile, the effect of vitamin D supplementation on liver enzymes of ALT and AST showed varying results. Vitamin D supplementation decrease ALT levels, with pooled mean difference of $-4.44(p=0.02 ; 95 \% \mathrm{Cl}$ : -8.24 to -0.65$)$

(Fig. 5). However, no effect observed for AST levels, with pooled mean difference of -5.28 ( $p=0.14 ; 95 \% \mathrm{Cl}:-12.34$ to 1.79$)$

(Fig. 6), based on random effect model.

\section{Discussion}


The pooled result of the current meta-analysis found that additional vitamin $D$ treatment may improve insulin resistance, marked by decrease of HOMA-IR in patients with NAFLD. The route of vitamin D administration may vary, either intramuscular injection or oral. Its effect toward improvement of insulin resistance was further analyzed for changes in serum ALT and AST levels. A decrement in ALT levels was observed due to additional supplementation of vitamin D, but not for AST levels.

The occurrence of NAFLD closely related to insulin resistance. Increase free fatty acid (FFA), adipose tissue inflammation and decrease of adiponectin responsible to the development of insulin resistance in NAFLD. ${ }^{14}$ Patients with NAFLD possess significant elevation of serum FFA, subsequently converted to triacylglycerol by the glycerol-3-phosphate pathway. The other product of this pathway is ceramides and diacylglycerols (DAGs). It has been known that DAG involved in activation of protein kinase C (PKC), which may inhibit insulin receptor threonine 1160, linked to reduced insulin resistance. ${ }^{15}$ Adipose tissue inflammation, along with increased of proinflammatory cytokines such as interleukin 6 (IL-6) and tumor necrosis factor alpha (TNF-a), also lead to insulin resistance. As for adiponectin, it may promotes fatty acid $\beta$-oxidation (FAO), glucose utilization, and suppression of fatty acid synthesis. Its level decrease in NAFLD patients, hence promote the development of insulin resistance. ${ }^{14}$

Current evidence showed that vitamin D deficiency may related to pathogenesis of several diseases. This concept is true for linked between vitamin D deficiency and insulin resistance. ${ }^{16,17}$ Vitamin D exert its potential effect through its interaction with vitamin D receptor (VDR) and vitamin D-metabolizing enzymes. Those may be found in several cell types, including pancreatic $\beta$-cells and insulin-responsive cells such as adipocytes. Although the definite mechanism between vitamin $D$ and insulin resistance still uncertain, it has been suggested that adipose tissue may be related to its mechanism. The major vitamin $D$ storage in the body is adipose tissue, it also served as notable source of adipokine and cytokines, involved in the generation of systemic inflammation. ${ }^{18}$ Current evidence suggested that vitamin D regulate the events involved in insulin secretion of pancreatic $\beta$-cells. ${ }^{19}$

Given such evidences, it is rational for additional vitamin D to improve insulin resistance in NAFLD patients. Recent reports pointed out the beneficial effect of vitamin $D$ addition for improvement in insulin resistance. Several RCTs provide conflicting results, lead to the necessity of further evaluation through meta-analysis. Recent meta-analysis by Guo et al to assess the effect of vitamin D on insulin resistance provide substantial evidence that vitamin D may have favorable effect on insulin sensitivity. They found reduction in HOMA-IR by $-1.32 ; 95 \% \mathrm{Cl}:-2.30,-0.34$. The studies included for the evaluation of HOMA-IR were six studies. ${ }^{20}$ However, conflicting evidence do exist. A systematic review and meta-analysis by Pramono et al, involving 18 RCTs, that evaluate the effect of vitamin D supplementation on insulin sensitivity in subjects with or at risk for insulin resistance showed that additional vitamin $D$ treatment showed no effect of insulin sensitivity, with standardized mean difference of $-0.01,95 \% \mathrm{Cl}-0.12,0.10 ; \mathrm{P}=0.87,12=0 \% .{ }^{21}$ However, it should be noted that the population evaluated in the meta-analysis was subjects with or at risk for insulin resistance (overweight, obesity, prediabetes, polycystic ovary syndrome [PCOS], and type 2 diabetes without complications), not NAFLD patients. ${ }^{21}$ Another meta-analysis by Wei et al also obtained similar finding. In the evaluation of vitamin D supplementation for HOMA-IR, which included four studies, vitamin D supplementation did not exert reduction in HOMA IR $(\mathrm{WMD}=0.380,95 \% \mathrm{Cl}:-0.162,0.923 ; \mathrm{P}=0.169) .{ }^{22}$ Comparing all the data available, the current systematic review and meta-analysis provide more reports that vitamin $\mathrm{D}$ supplementation improve insulin resistance in NAFLD patients, similar to meta-analysis by Guo et al. Although similar meta-analysis had been conducted, the current meta-analysis provide updated literature with more RCTs involved, hence providing stronger evidence for the effect of vitamin D supplementation on insulin resistance.

The effect of vitamin $D$ on insulin resistance may be explained by its effect as potential regulator of insulin secretion and $\mathrm{Ca}^{2+}$ levels. Calcitriol may directly trigger insulin secretion, since vitamin D responsive elements (VDRE) present in insulin gene promoter, located at $\beta$-cells of pancreas. ${ }^{23}$ Not only the transcription of insulin gene, VDRE also known to stimulate various genes related to cytoskeletal formation, intracellular junctions and cellular growth of pancreatic c $\beta$-cells. ${ }^{24}$ Vitamin D also showed effect to insulin resistance through its regulation in $\mathrm{Ca}^{2+}$ flux. As calcium is essential for several insulin-mediated intracellular processes in muscle an adipose tissue, hence vitamin D may be related to its effect on insulin resistance. Optimal 
intracellular level of $\mathrm{Ca}^{2+}$ is a mandatory for insulin action. Studies has found that vitamin D deficiency responsible for increase concentration of $\mathrm{Ca}^{2+}$, leading to decrease activity of GLUT-4, impacting in insulin resistance. ${ }^{25,26}$

The effect of improvement of insulin resistance due to vitamin D supplementation further analyzed towards its effect to liver function, reflected by changes in ALT and AST levels. A decrement in ALT levels was observed due to additional supplementation of vitamin D, but not for AST levels. A meta-analysis by Guo et al showed a borderline reduction in ALT levels and no effect toward AST levels, similar to this study. ${ }^{20}$ Another meta-analysis study by Wei et al in 2020 also found that serum alanine aminotransferase and aspartate aminotransferase levels were not different between vitamin D supplementation and placebo groups. ${ }^{22}$

The current systematic review and meta-analysis also objected to limitation. The heterogeneity of the current meta-analysis may affect the results obtained in the current study. The future perspective should be directed to the number of study and subjects involved in the evaluation of vitamin D supplementation toward insulin resistance, specified to NAFLD population, and its homogeneity of the studies. To conclude, vitamin D supplementation improve insulin resistance in NAFLD patients, marked by the decrease of HOMA-IR. It may serve as potential adjunctive treatment for NAFLD patients.

\section{Methods}

\section{Eligibility Criteria}

The eligibility criteria decided by implementing PICO concept. The framework depicted in Table 2.

Table 2

PICO framework of the study

\begin{tabular}{|ll|}
\hline Patient & NAFLD patients \\
\hline Intervention & Vitamin D Supplementation \\
\hline Comparator & Placebo \\
Outcome & Insulin resistance by HOMA-IR \\
\hline
\end{tabular}

\section{Type of Studies}

The current systematic review and meta-analysis included all studies prior to March 28th 2021 with full-text available, evaluating the additional administration of vitamin D in NAFLD patients. Article with the type of case report, qualitative and economic studies, review, cadaveric and anatomic were excluded from the current study. All articles which did not provide the required data needed for conducted the current meta-analysis also did not included. To prevent the duplication of sample, articles written by the same author within the same institution were evaluated for the samples.

\section{Type of Participants}

This review included studies with adult NAFLD patients who receive vitamin D administration. Insulin resistance assessed using Homeostatic Model Assessment for Insulin Resistance (HOMA-IR).

\section{Type of Intervention}

The reviewed intervention is administration of vitamin $D$. We included studies which administered vitamin $D$ for any doses, any method of delivery and any duration. However, we noted both the doses and the duration of vitamin $D$ given for each studies.

\section{Type of Outcomes}

The primary outcome investigated in the current systematic review and meta-analysis was the insulin resistance. In this regard, we use HOMA-IR to determine the insulin resistance of the patients. The secondary outcome including serum vitamin $D$ 
levels (ng/mL), alanine aminotransferase (ALT) (IU/I) and aspartate aminotransferase (AST) (IU/I) levels.

\section{Information Sources}

The eligibility criteria (PICO) extracted into keywords utilizing Boolean operator. In this study, we used keywords (NAFLD OR non alcoholic fatty liver disease OR NASH OR non alcoholic steatohepatitis) AND (Vitamin D OR Vitamin D3 OR Cholecalciferol OR ergocalciferol) AND (Insulin sensitivity OR HOMA-IR) in PubMed database, Google Scholar, COCHRANE, and Science Direct as search engine to find eligible journals.

\section{Study Selection}

The study selection process was conducted by three authors (DAS, IKM, GS) in order to minimize the likelihood of expunge the potentially relevant studies. When disagreement took place, the decision of the first, second and third author was considered. Study selection started with disposing of duplicate records. Title and abstract screening were performed to exclude the irrelevant studies. Subsequently, studies that passed the first evaluation were further evaluated, in order to evaluate its compliance for the inclusion and exclusion criteria for this review. All studies included were evaluated thoroughly for its quality before eventually included.

\section{Data Collection Process}

All authors used electronic data collection form to collect the required data from each of the articles. The data then combined and managed with software Review Manager 5.4.

\section{Data Items}

The data items were the author's name, year of publication, type of study, population, doses of vitamin $D$, duration of vitamin D administration, sample size, age and baseline HOMA-IR. The mean difference of HOMA-IR after and before administration of vitamin D in both treatment and control group for respective duration were performed the meta-analysis.

\section{Assessment of Quality of Study}

To ensure the quality of all articles which complied with the eligibility criteria for this review, a standardized critical appraisal tool was utilized. This process, which aimed to minimize the likelihood for bias in study selection, performed independently by two authors (DAS and IKM).

The critical appraisal tool employed for this review was Cochrane Collaboration's risk-of-bias method.

\section{Synthesis of Result}

The mean difference of HOMA-IR in NAFLD patients with administration and without administration of vitamin D were pooled and analyzed. If data presented as median with Q1 and Q3, the mean was calculated using calculator. Meta-analysis was conducted using software Review Manager 5.4.

\section{Declarations}

\section{Author Contributions Statement}

DAS: conception, data extraction and validation, initial draft, analysis, manuscript review, and approval. IDNW: data extraction, initial draft, manuscript review, and approval. DAS, IKM, and GS: data extraction and validation, manuscript review, and approval. IDNW, DAS, and IKM: important intellectual content, manuscript review, and approval. GS: conception, data extraction, validation, initial draft, important intellectual content, manuscript review, and approval.

\section{Funding}

None 
Conflict of interest Dwijo Anargha Sindhughosa, I Dewa Nyoman Wibawa, I Ketut Mariadi and Gde Somayana declare that they have no conflict of interest.

\section{References}

1. Wang, S. et al. Vitamin D supplementation for nonalcoholic fatty liver disease in type 2 diabetes mellitus: A protocol for a systematic review and meta-analysis. Medicine. 99(19), e20148, DOI: https://doi.org/10.1097/MD.0000000000020148 (2020).

2. Barchetta, I. et al. Present and Future. Nutrients, 9 (9), 1015 https://doi.org/10.3390/nu9091015 (2017).

3. Bellentani, S. \& Marino, M. Epidemiology and natural history of non-alcoholic fatty liver disease (NAFLD). Annals of hepatology. 8 Suppl 1,S4-S8, PMID:PMID: 19381118 (2009).

4. Vernon, G., Baranova, A. \& Younossi, Z. M. Systematic review: the epidemiology and natural history of non-alcoholic fatty liver disease and non-alcoholic steatohepatitis in adults. Alimentary pharmacology \& therapeutics. 34(3), 274-285. DOI: https://doi.org/10.1111/j.1365-2036.2011.04724.x (2011).

5. Paschos, P. \& Paletas, K. Non alcoholic fatty liver disease two-hit process: multifactorial character of the second hit. Hippokratia. 13(2), 128, PMCID: PMC2683460(2009).

6. Iruzubieta, P., Terán, Ã., Crespo, J. \& Fábrega, E. Vitamin D deficiency in chronic liver disease. World journal of hepatology, 6 (12), 901-915 https://doi.org/10.4254/wjh.v6.i12.901 (2014).

7. Amiri, H. L., Agah, S., Mousavi, S. N., Hosseini, A. F. \& Shidfar, F. Regression of Non-Alcoholic Fatty Liver by Vitamin D Supplement: A Double-Blind Randomized Controlled Clinical Trial. Archives of Iranian medicine. 19(9), 631-638, PMID: 27631178(2016).

8. Barchetta, I. et al. No effects of oral vitamin D supplementation on non-alcoholic fatty liver disease in patients with type 2 diabetes: a randomized, double-blind, placebo-controlled trial. BMC medicine, 14, 92 https://doi.org/10.1186/s12916-0160638-y (2016).

9. Foroughi, M., Maghsoudi, Z. \& Askari, G. The effect of vitamin D supplementation on blood sugar and different indices of insulin resistance in patients with non-alcoholic fatty liver disease (NAFLD). Iranian journal of nursing and midwifery research, 21 (1), 100-104 https://doi.org/10.4103/1735-9066.174759 (2016).

10. Hussain, M. et al. Effect of vitamin D supplementation on various parameters in non-alcoholic fatty liver disease patients. Pakistan journal of pharmaceutical sciences. 32(3 Special), 1343-1348, PMID: 31551213(2019).

11. Sakpal, M. et al. Vitamin D supplementation in patients with nonalcoholic fatty liver disease: A randomized controlled trial. JGH open: an open access journal of gastroenterology and hepatology, 1 (2), 62-67 https://doi.org/10.1002/jgh3.12010 (2017).

12. Sharifi, N., Amani, R., Hajiani, E. \& Cheraghian, B. Does vitamin D improve liver enzymes, oxidative stress, and inflammatory biomarkers in adults with non-alcoholic fatty liver disease? A randomized clinical trial. Endocrine, 47 (1), 70-80 https://doi.org/10.1007/s12020-014-0336-5 (2014).

13. Vesna, L. Z. et al. Vitamin D for treatment of non-alcoholic fatty liver disease detected by transient elastography: A randomized, double-blind, placebo-controlled trial. Diabetes, obesity \& metabolism, 22 (11), 2097-2106 https://doi.org/10.1111/dom.14129 (2020).

14. Khan, R. S., Bril, F., Cusi, K. \& Newsome, P. N. Modulation of Insulin Resistance in Nonalcoholic Fatty Liver Disease. Hepatology (Baltim., Md.), 70 (2), 711-724 https://doi.org/10.1002/hep.30429 (2019).

15. Petersen, M. C. et al. I. Insulin receptor Thr1160 phosphorylation mediates lipid-induced hepatic insulin resistance. The Journal of clinical investigation, 126 (11), 4361-4371 https://doi.org/10.1172/JCl86013 (2016).

16. Wang, H. et al. Vitamin D and Chronic Diseases. Aging and disease, 8 (3), 346-353

https://doi.org/10.14336/AD.2016.1021 (2017). 
17. Tao, S. et al. Vitamin D deficiency causes insulin resistance by provoking oxidative stress in hepatocytes. Oncotarget, 8 (40), 67605-67613 https://doi.org/10.18632/oncotarget.18754 (2017).

18. Abbas, M. A. Physiological functions of Vitamin D in adipose tissue. The Journal of steroid biochemistry and molecular biology. 165(Pt B), 369-381, DOI: https://doi.org/10.1016/j.jsbmb.2016.08.004 (2017).

19. Szymczak-Pajor, I. \& Śliwińska, A. Analysis of Association between Vitamin D Deficiency and Insulin Resistance. Nutrients, 11 (4), 794 https://doi.org/10.3390/nu11040794 (2019).

20. Guo, X. F. et al. Vitamin D and non-alcoholic fatty liver disease: a meta-analysis of randomized controlled trials. Food \& function, 11 (9), 7389-7399 https://doi.org/10.1039/d0fo01095b (2020).

21. Pramono, A., Jocken, J., Blaak, E. E. \& van Baak, M. A. The Effect of Vitamin D Supplementation on Insulin Sensitivity: A Systematic Review and Meta-analysis. Diabetes care. 43(7), 1659-1669, DOI: https://doi.org/10.2337/dc19-2265 (2020).

22. Wei, Y. et al. Effects of Vitamin D Supplementation in Patients with Nonalcoholic Fatty Liver Disease: A Systematic Review and Meta-Analysis. International journal of endocrinology and metabolism, 18 (3), e97205 https://doi.org/10.5812/ijem.97205 (2020).

23. Altieri, B. et al. Vitamin D and pancreas: The role of sunshine vitamin in the pathogenesis of diabetes mellitus and pancreatic cancer. Critical reviews in food science and nutrition, 57 (16), 3472-3488 https://doi.org/10.1080/10408398.2015.1136922 (2017).

24. Wolden-Kirk, H. et al. Unraveling the effects of 1,250H2D3 on global gene expression in pancreatic islets. The Journal of steroid biochemistry and molecular biology, 136, 68-79 https://doi.org/10.1016/j.jsbmb.2012.10.017 (2013).

25. Reusch, J. E., Begum, N., Sussman, K. E. \& Draznin, B. Regulation of GLUT-4 phosphorylation by intracellular calcium in adipocytes. Endocrinology, 129 (6), 3269-3273 https://doi.org/10.1210/endo-129-6-3269 (1991).

26. Draznin, B. et al. Mechanism of insulin resistance induced by sustained levels of cytosolic free calcium in rat adipocytes. Endocrinology, 125 (5), 2341-2349 https://doi.org/10.1210/endo-125-5-2341 (1989).

\section{Figures}




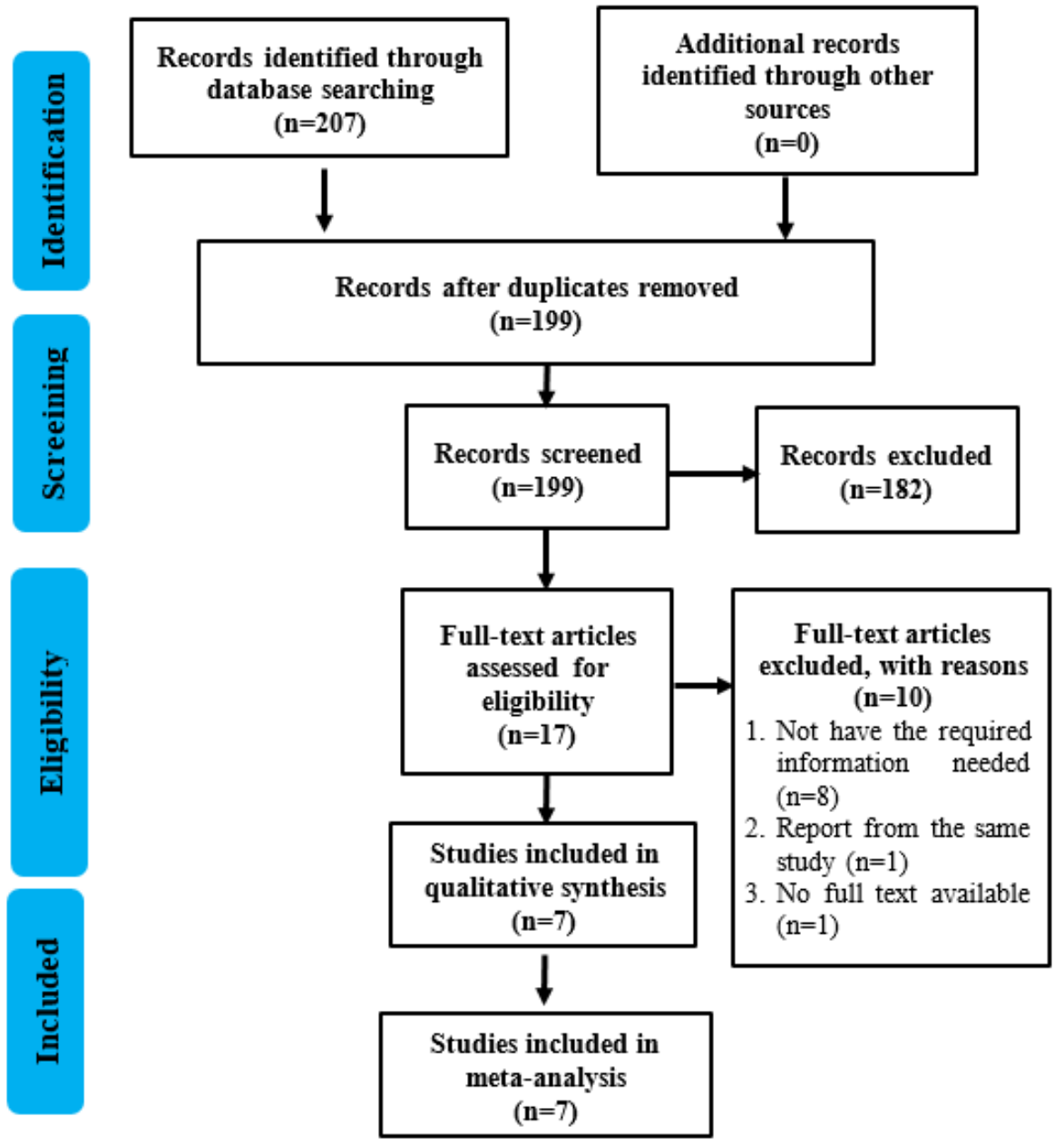

Figure 1

PRISMA Flow Diagram 


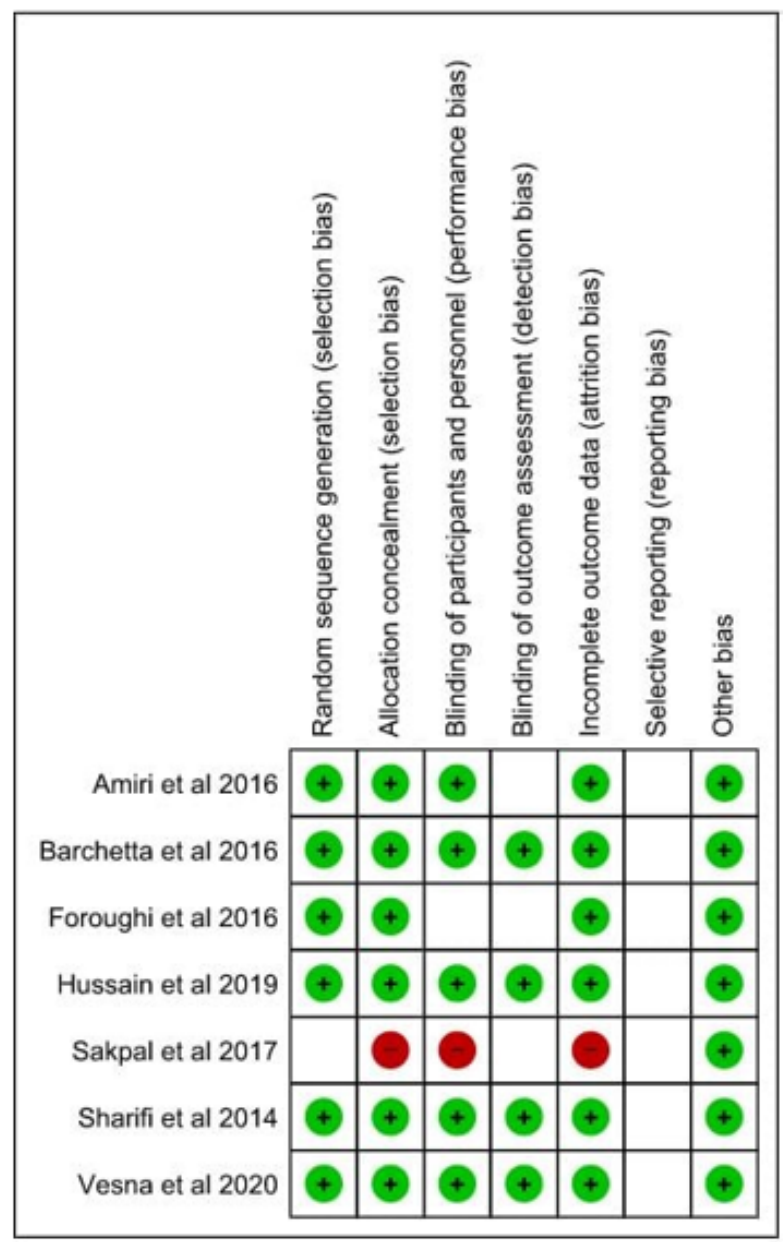

Figure 2

Risk of bias within studies

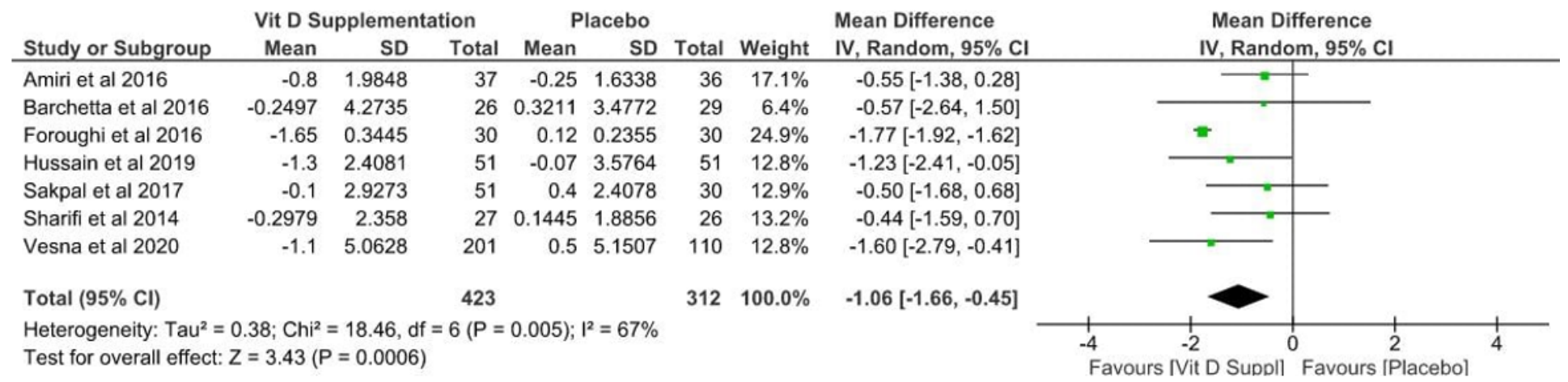

\section{Figure 3}

Forest Plot of Insulin Resistance 


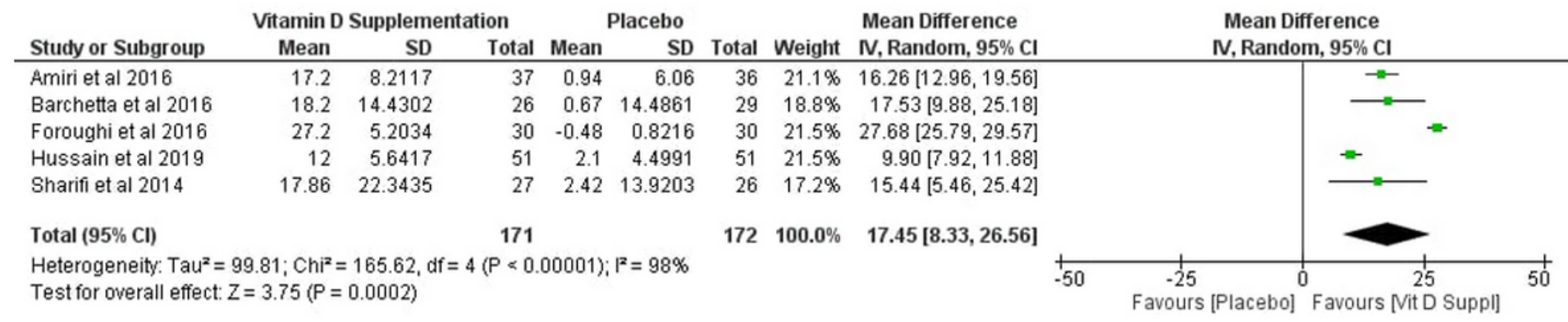

\section{Figure 4}

Forest Plot of vitamin D serum

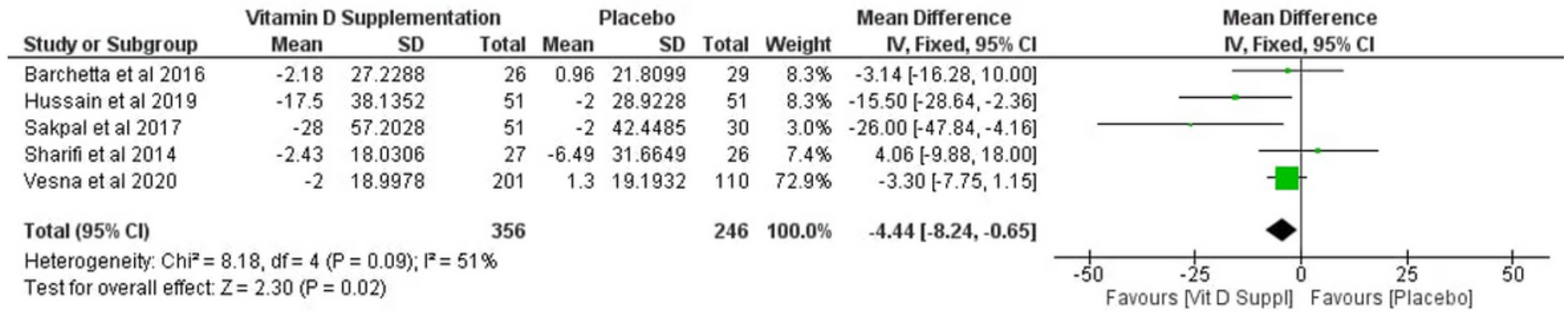

\section{Figure 5}

Forest Plot of ALT levels

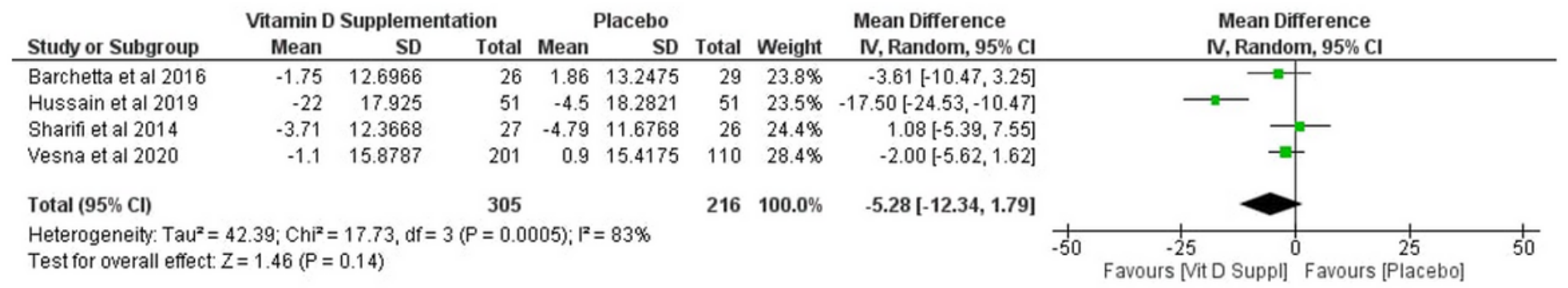

\section{Figure 6}

Forest Plot of AST levels 